\title{
ANALISIS KINERJA KEUANGAN MENGGUNAKAN RASIO KEUANGAN PADA PT GOWA MAKASSAR TOURISM DEVELOPMENT TBK
}

\author{
Dirwan $^{*}$, Gusmi Haerani² \\ Dosen STIE Nobel Indonesia, Alumni STIE Nobel Indinesia \\ E-mail : dirwan@stienobel-indonesia.ac.id
}

\begin{abstract}
The formulation of the probelem is research is how performance PT Gowa Makassar Tourism Development Tbk measured based on the analysis of financial flows using financial statements using financial ratio analysis method. The method of analysis used is financial ratios which include: liquidity, solvency, profitability and activity. The results show the performance of PT Gowa Makassar Tourism Development Tbk which was on the liquidity ratio in 2014 to 2016 was in good condition, where the Current Ratio (CR) of the company in 2014 to 2016 was more than 100\% which means PT GMTD Tbk able to pay all obligation smoothly with current assets available. Overall quick ratio (QR) had a poor performance due to the increase in the value of current debt. The condition Solvency ratio of PT Gowa Makassar Tourism Development Tbk was good enorghin 2014 until 2016, which Debt To Assets Ratio (DAR) company in 2014 until 2016 more then 100\%. This percentage indicates that the financial condition was quite good because their debt as financing for large assets compared with own capital. Performance in debt to equity ratio (DER) Companies was not good because DER greater than 90\% indicates that the sources of the companis assets financing comes more from debt than its own capital. Profitability ratio of PT Gowa Makassar Tourism Development Tbk in 2014 until 2016 was good, where the result of the profitabily ratio is higher then one year time deposit interest rates. The activity ratio of PT Gowa Makassar Tourism Development Tbk in 2014 to 2016 was good, where Total Assets Turn Over (TATO) is more then 1 (one), that means the company, was productive in generating sales.
\end{abstract}

Keywords: financial statement analysis, financial performance, financial ratio

\section{PENDAHULUAN}

Dewasa ini, banyak perusahaan berskala besar atau kecil baik yang bersjfat profit maupun non profit, mempunyai perhatian yang besar di bidang keuangan. Ribo (2013) berpendapat, "Dalam perkembangan dunia usaha yang semakin maju, persaingan antara satu perusahaan dengan perusahaan lainnya semakin tinggi mengakibatkan adanya perusahaan yang tiba-tiba mengalami kemunduran. Oleh karena itu, agar perusahaan dapat bertahan dan bisa terus berkembang, perusahaan harus mencermati kondisi dan kinerja keuangan perusahaan. Untuk mengetahui dengan tepat bagaimana kondisi dan kinerja keuangan perusahaan, maka dibutuhkan pula suatu analisis yang tepat".

Perusahaan butuh analisis yang tepat agar mengetahui kondisi dan kinerja Keuangan perusahaan, salah satunya PT Gowa Makassar Tourism Development Tbk. Data BEI mencatat bahwa PT Gowa Makssar Tourism Development Tbk termasuk perusahaan yang aktivitas usahanya bergerak di bidang properti, PT Gowa Makssar Tourism Develoment Tbk merupakan perusahaan yang memiliki karya besar dan kontribusi besar bagi masyarakat Makassar, di mana berkaitan dengan 
pentingnya masalah pengukuran kinerja keuangan, maka hal ini perlu diterapkan pada perusahaan tersebut. Menurut Jumigan (2006:242) salah satu alat analisis untuk mengukur kinerja keuangan perusahaan yaitu dengan menggunakan analisis rasio keuangan.

PT GMTD Tbk telah mencatatkan dirinya sebagai perusahaan pertama yang berdomisili di Kota Makassar yang menjadi Perusahaan Terbuka. Bagi PT GMTD Tbk, dengan telah go-public tersebut berarti akan memberi peluang bisnis yang lebih luas serta semakin memperkuat posisi perusahaan di era persaingan pasar bebas, sehingga menurut peneliti hal tersebut yang melatar belakangi untuk melakukan penelitian di perusahaan tersebut yang mana perusahaan yang aktivitas usahanya bergerak di bidang properti, memiliki karya besar dan kontribusi besar bagi masyarakat Makassar.

Berikut merupakan tabel yang menggambarkan posisi keuangan perusahaan PT Gowa Makassar Tourism Develompment Tbk, untuk periode tahun 2014-2016.

Tabel 1. Pertumbuhan Kinerja Keuangan Perusahaan PT Gowa Makassar Tourism Development Tahun 2014-2016

\begin{tabular}{ccc}
\hline Tahun & Pertumbuhan Penjualan & Pertumbuhan Laba Bersih \\
\hline $\mathbf{2 0 1 4}$ & 301.319 .818 .199 & 121.742 .954 .148 \\
$\mathbf{2 0 1 5}$ & 303.342 .488 .851 & 118.892 .415 .913 \\
$\mathbf{2 0 1 6}$ & 276.272 .327 .077 & 86.914 .558 .620 \\
\hline
\end{tabular}

Sumber: www.idx.co.id

Dalam penelitian ini penulis mengukur kinerja keuangan perusahaan dengan menggunakan pendekatan analisis rasio keuangan untuk menilai kondisi keuangan dan prestasi perusahaan. Untuk mengetahui kemampuan perusahaan dalam memenuhi kewajiban atau hutang dalam jangka waktu pendek, perusahaan dapat mengukur dengan menggunakan rasio likuiditas. Untuk mengukur sejauh mana perusahaan mendanai usahanya dengan membandingkan antara dana sendiri yang telah disetorkan dengan jumlah pinjaman dari para kreditur, perusahaan dapat mengukur dengan menggunakan rasio solvabilitas. Untuk mengetahui kemampuan perusahaan dalam menghasilkan laba melalui semua kemampuan dan sumber yang ada seperti kegiatan penjualan, kas, modal, jumlah karyawan, jumlah cabang, dan sebagainya, perusahaan dapat mengukur dengan menggunakan rasio profitabilitas. Sementara itu untuk mengukur efektifitas perusahaan dalam menggunakan modal yang tersedia dapat mengukur dengan menggunakan rasio aktivitas (Astuti, 2004).

Berdasarkan uraian dan penjelasan dari latar belakang yang dikemukakan sebelumnya, maka penulis merumuskan masalah penelitian yaitu: Bagaimana kinerja keuangan PT Gowa Makassar Tourism Development Tbk, diukur berdasarkan analisis laporan keuangan dengan menggunakan metode analisis rasio keuangan?

\section{Tujuan Penelitian}

Tujuan dari penelitian ini adalah untuk mengetahui kinerja keuangan PT Gowa Makassar Tourism Development Tbk, yang diukur berdasarkan analisis laporan keuangan dengan menggunakan metode rasio keuangan.

\section{Manfaat Penelitian}

Kegunaan praktis yang diperoleh dari penelitian ini adalah:

1. Bagi penulis 
Penelitian ini diharapkan dapat menambah pengetahuan, wawasan serta informasi penulis, khususnya mengenai kinerja keuangan yang diukur berdasarkan analisis laporan keuangan suatu perusahaan.

2. Perusahaan

Penellitian diharapkan memberikan informasi, masukan, dan evaluasi yang berguna bagi perusahaan sebagai bahan pertimbangan, perbaikan dan penyempumaan dalam pengembangan kondisi keuangan perusahaan serta proses pengambilan keputusan.

3. Bagi masyarakat

Penelitian ini bermanfaat untuk menambah pengetahuan masyarakat akan kinerja keuangan yang diukur berdasarkan analisis laporan keuangan suatu perusahaan.

4. Bagi praktisi

Penelitian ini dapat memberikan gambaran mengenai pentingnya menganalisi laporan keuangan untuk mengukur kinerja keuangan suatu perusahaan.

\section{Tinjauan Pustaka}

\section{Kinerja Keuangan}

Kinerja keuangan adalah ukuran prestasi perusahaan Jones Charles (1998:9). Menurut Mulyadi (2007:415) menyatakan bahwa kinerja keuangan adalah penentuan secara periodik efektivitas operasional suatu organisasi dan karyawannya berdasarkan sasaran, standar dan kriteria yang telah diharapkan sebelumnya. Sedangkan Muslich (2000:44) menyatakan bahwa kinerja keuangan adalah prestasi keuangan yang tergambar dalam laporan keuangan perusahaan yaitu neraca, labarugi dan kinerja keuangan menggambarkan usaha perusahaan (operating income). Profitability suatu perusahaan dapat diukur dengan menghubungkan keuntungan yang diperoleh dari kegiatan pokok perusahaan dengan kekayaan asset yang digunakan untuk menghasilkan keuntungan. Kinerja keuangan suatu perusahaan dapat diartikan sebagai prospek atau masa depan, pertumbuhan dan potensi perkembangan yang baik bagi perusahaan. Informasi kinerja keuangan diperlukan untuk menilai perubahan potensial sumber daya ekonomi, yang mungkin dikendalikan di masa depan dan untuk memprediksi kapasitas produksi dan sumber daya yang ada, Ribo (2013).

Evaluasi kinerja keuangan dapat dilakukan menggunakan analisis laporan keuangan, dimana data pokok sebagai input dalam analisis ini adalah neraca dan laporan laba rugi. Analisis laporan keuangan dapat dilakukan menggunkan rasio keuangan. Analisis rasio keuangan memungkinkan manajer keuangan dan pihak yang berkepentingan untuk mengevaluasi kondisi keuangan dengan cepat, karena penyajian rasio-rasio keuangan akan menunjukkan kondisi sehat tidaknya suatu perusahaan. Analisis rasio menghubungkan unsurunsur rencana dan perhitungan laba rugi sehingga dapat menilai efektivitas dan efisiensi perusahaan.

\section{Rasio Keuangan}

Rasio keuangan digunakan untuk membandingkan risiko dan tingkat imbal hasil dari berbagai perusahaan untuk membantu investor dan kreditor membuat keputusan investasi dan kredit yang baik (White et al., 2002). Agar dapat mengevaluasi kondisi keuangan perusahaan dan kinerjanya, analisis keuangan perlu melakukan pemeriksaan atas berbagai aspek kesehatan keuangan perusahaan.

\section{Definisi Rasio Keuangan}

Menurut Susan Irawati (2006:22), Rasio keuangan merupakan suatu teknik analisis dalam bidang manajemen keuangan yang dimanfaatkan sebagai alat ukur kondisi-kondisi keuangan suatu perusahaan dalam periode tertentu ataupun hasil- hasil usaha dari suatu 
perusahaan pada setiap periode tertentu dengan jalan membandingkan dua buah variabel yang diambil dari laporan keuangan perusahaan, baik daftar neraca maupun laporan laba rugi.

Dalam menggunakan rasio keuangan diperlukan laporan keuangan perusahaan. Laporan keuangan perlu dianalisis karena akan diperoleh semua informasi yang menyangkut dengan posisi dan kondisi keuangan perusahaan, menurut Harahap (2004:297), bahwa analisis rasio adalah suatu metode analisis untuk mengetahui hubungan dari pos-pos tertentu dalam neraca atau laporan laba rugi secara individu atau kombinasi dari kedua laporan tersebut.

Berdasarkan uraian diatas bahwa analisis rasio keuangan digunakan sebagai alat ukur untuk menilai baik atau buruknya kondisi keuangan perusahaan. Manfaat Rasio Keuangan

Analisis rasio keuangan perusahaan merupakan langkah awal dalam analisis keuangan, karena fungsi rasio keuangan yang dirancang dapat digunakan untuk memberi gambaran hubungan perkiraanperkiraan laporan keuangan.

Menurut Susan Irawati (2006:24) bahwa manfaat dari rasio keuangan dapat ditinjau dari dua sudut, yaitu:

1. Pihak Intern (Manaj emen)

2. Pihak Ekstern (Investor)

Manfaat rasio keuangan tersebut dapat dijelaskan sebagai berikut:

1. Pihak Intern (Manajemen)

Dalam sudut pandang pihak intern perusahaan atau manajemen, analisis rasio keuangan berguna sebagai cara untuk:

a. Mengantisispasi keadaan di masa mendatang, dan

b. Sebagai titik tolak bagi tindakan perencanaan yang akan mempengaruhi jalannya kejadian di masa mendatang.

2. Pihak Ekstern (Investor)

Dalam sudut pandang pihak ekstern manfaat dari rasio keuangan yaitu untuk meramalkan masa depan perusahaan, atau dengan kata lain dari sudut pandang pihak ekstern manfaat rasio keuangan yaitu untuk menentukan prediksi apakah perusahaan tersebut bisa berkembang dalam arti dapat melakukan operasionalnya kembali atau malah perusahaan tersebut gulung tikar, sehingga akan mempengaruhi keberadaan pihak ekstem di dalam perusahaan tersebut.

\section{Analisis Rasio Keuangan}

Untuk menilai kondisi keuangan dan prestasi perusahaan, analisis laporan keuangan memerlukan beberapa tolak ukur. Tolak ukur yang sering digunakan adalah rasio atau indeks yang menghubungkan dua data keuangan yang satu dengan yang lainnya. Analisis dan interpretasi dari macam-macam rasio dapat memberikan pandangan yang lebih baik tentang kondisi keuangan dan prestasi perusahaan.

Dalam Ardiyos (2008) Analisis rasio keuangan adalah perbandingan matematis yang menunjukkan hubungan antara pos-pos laporan keuangan, bersifat informatif untuk memberikan gambaran kepada penganalisa tentang baik buruknya keadaan atau posisi keuangan suatu perusahaan terutama apabila angka rasio tersebut dibandingkan dengan angka rasio pembanding yang digunakan sebagai standar. Dengan menganalisa rasio kita dapat menentukan tingkat likuidutas dari perusahaan.

Analisis rasio keuangan ini hanya menyempurnakan informasi yang menggambarkan hubungan antara pos tertentu dengan pos lainnya. Dengan penyederhanaan ini kita dapat menilai secara cepat hubungan antara pos-pos tersebut dan dapat membandingkan dengan rasio lain sehingga kita dapat memperoleh informasi dan memberikan penilaian. (Harahap, 2011:297).

\section{A. Rasio Likuiditas}


Rasio likuiditas (liquidity ratio) adalah kemampuan suatu perusahaan memenuhi kewajiban jangka pendeknya secara tepat waktu. Contoh: membayar listrik, telepon, air PDAM, gaji karyawan, gaji teknisi, gaji lembur, tagihan telepon, dan sebagainya karena itu rasio likuiditas sering disebut dengan short term liquidity, Irham Fahmi (2014:59).

Rasio likuiditas secara umum ada 3 (tiga) yaitu current ratio, quick ratio dan net working capital ratio.

a. Rasio Lancar (Current Ratio)

Current Ratio merupakan rasio untuk mengukur kemampuan perusahaan dalam membayar kewajiban jangka pendek atau hutang yang segera jatuh tempo pada saat ditagih secara keseluruhan.

\section{b. Rasio Cepat (Quick Ratio)}

Quick Ratio merupakan rasio yang menunjukkan kemampuan perusahaan dalam memenuhi atau membayar kewajiban atau hutang lancar dengan aktiva lancar tanpa memperhitungkan nilai perusahaan.

c. Cash Ratio

Rasio ini merupakan rasio yang menunjukkan kemampuan perusahaan dalam memenuhi kewajiban jangka pendek perusahaan dengan uang kas yang tersedia didalam perusahaan.

\section{B. Rasio Solvabilitas (Leverage Ratio)}

Rasio solvabilitas adalah

mengukur seberapa besar perusahaan dibiayai dengan utang. Penggunaan utang yang terlalu tinggi akan membahayakan perusahaan karena perusahaan akan masuk dalam kategori extreme leverage (utang ekstrem) yaitu perusahaan terjebak dalam tingkat utang yang tinggi dan sulit untuk melepaskan beban utang tersebut. Karena itu sebaiknya perusahaan harus menyeimbangkan berapa utang yang layak diambil dan dari mana sumber- sumber yang dapat dipakai untuk membayar utang, (Fahmi,
2014:62).

Rasio solvabilitas secara umum ada 3 (tiga) yaitu debt to assets ratio, debt to equty ratio, dan Interest Coverage.

a. Debt to Assets Ratio (DAR)

Rasio yang digunakan untuk menunjukkan berapa total aktiva yang disediakan untuk menjamin hutang perusahaan.

b. Debt to Equity Ratio (DER)

Rasio yang digunakan untuk menggambarkan sejauh mana modal pemilik dapat menutupi hutang-hutang kepada pihak luar. Semakin kecil rasio ini maka semakin baik.

\section{Rasio Profitabilitas}

Rasio yang mengukur efektifitas manajemen secara keseluruhan yang ditujukan oleh besar kecilnya tingkat keuntungan yang diperoleh dalam hubungannya dengan penjualan maupun investasi. Semakin baik rasio profitabilitas maka semakin baik menggambarkan kemampuan tingginya perolehan keuntungan perusahaan, (Fahmi, 2014:68). Rasio profitabilitas secara umum ada 4 (empat), yaitu net profit margin (NPM), gross profit margin (GPM), return on assets (ROA) dan, return on equity (ROE).

\section{Rasio Aktivitas}

Rasio aktivitas adalah rasio yang menggambarkan sejauh mana suatu perusahaan mempergunakan sumber daya yang dimilikinya guna menunjang aktivitas perusahaan, (Fahmi, 2014:65). Rasio aktivitas secara umum ada 5 (lima), yaitu total assets turn over, Inventory Turn Over, Rata-rata Penerimaan Piutang, Lama Persediaan Mengendap, Receivable Turn Over.

Keunggulan Analisis Rasio Keuangan Fahmi (2014), analisis rasio mempunyai keunggulan sebagai berikut:

a. Rasio merupakan angka-angka atau ikhtisar statistik yang lebih mudah dibaca dan ditafsirkan;

b. Merupakan pengganti yang lebih 
sederhana dari informasi yang disajikan laporan keuangan yang sangat rinci dan rumit;

c. Mengetahui posisi perusahaan ditengah industri lain;

d. Sangat bermanfaat untuk bahan dalam mengisi model-model pengambilan keputusan dan model prediksi (Z-score);

e. Menstandardisasi size perusahaan;

f. Lebih mudah memperbandingkan perusahaan dengan perusahaan lain atau melihat perkembangan perusahaan secara periodik atau time series;

g. Lebih mudah melihat tren perusahaan serta melakukan prediksi di masa yang akan datang.

\section{Hubungan Rasio Keuangan dan Kinerja Keuangan}

Fahmi (2014) “Analsis rasio keuangan merupakan instrumen analisis prestasi perusahaan yang menjelaskan berbagai hubungan dan indikator keuangan, yang ditujukan untuk menunjukkan perubahan dalam kondisi keuangan atau prestasi operasi di masa lalu dan membantu menggambarkan tren pola perubahan tersebut, untuk kemudian menunjukkan risiko dan peluang yang melekat pada perusahaan yang bersangkutan".

Menurut James C. Van Horne dan John M. Wachowicz dalam Irham Fahmi (2014) bahwa: "Untuk mengevaluasi kondisi keuangan dan kinerja sebuah perusahaan, analisis keuangan membutuhkan tolak ukur tertentu. Ukuran yang sering digunakan adalah rasio, yang menghubungkan dua lembar data keuangan satu sama lain". Jadi untuk menilai kondisi dan kinerja keuangan perusahaan dapat digunakan rasio yang merupakan perbandingan angka-angka yang terdapat pada pos-pos laporan keuangan. Gitman dalam Irham Fahmi (2014), mengatakan bahwa, "Analisis rasio melibatkan metode perhitungan dan interpretasi rasio keuangan untuk menilai kinerja perusahaan. Masukan dasar untuk analisis rasio adalah laporan laba rugi perusahaan dan neraca".

Dari pandangan di atas dapat dimengerti bahwa rasio keuangan dan kinerja perusahaan mempunyai hubungan yang erat. Rasio keuangan ada banyak jumlahnya dan setiap rasio itu mempunyai kegunaan masing-masing. Bagi investor ia akan melihat rasio dengan penggunaan yang paling sesuai dengan analisis yang akan ia lakukan. Jika rasio tersebut tidak merepresentasikan tujuan dari analisis yang akan ia lakukan maka rasio tidak akan dipergunakan, karena dalam konsep keuangan dikenal dengan namanya fleksibelitas, artinya rumus atau berbagai bentuk formula yang dipergunakan haruslah disesuaikan dengan kasus yang diteliti (Fahmi, 2014).

\section{METODE PENELITIAN \\ Lokasi dan Waktu Penelitian}

Penelitian ini dilakukan pada Bursa Efak Indonesia dan Perusahaan PT Gowa Makassar Tourism Development Tbk, dengan menggunakan akses internet ke website resmi perusahaan yang bersangkutan serta link-link lainnya yang dianggap relevan. Penelitian ini dilakukan sejak tanggal 29 November 2017 sampai 25 Januari 2018.

\section{Teknik Pengumpulan Data}

Teknik pengumpulan data dilakukan menggunakanmetode dokumentasi terhadap data-data sekunder. Data sekunder yaitu data penelitian yang diperoleh secara tidak langsung melalui media perantara (diperoleh dan dicatat oleh pihak lain). Teknik pengumpulan data dalam penelitian ini dengan mengumpulkan data, mencatat data keuangan perusahaan real estate selama periode penelitian dari tahun 2014-2016 di Bursa Efek Indonesia. 


\section{Jenis dan Sumber Data}

Jenis data yang digunakan dalam penelitian ini:

1. Data kualitatif, yaitu data yang diperoleh dari PT Gowa Makassar Tourism development Tbk, dalam bentuk informasi yang bukan dalam bentuk angka. Data kualitatif ini seperti sejarah berderinya perusahaan, struktur organisasi, dan uraian tugas masing-masing bagian dalam PT. Gowa Makassar Tourism Development Tbk.

2. Data kuantitatif, yaitu data yang diperoleh dalam bentuk angka-angka. Data kuatitatif dalam penelitan ini bersumber dari laporan keuangan PT Gowa Makassar Tourism Development Tbk, yang telah diaudit Periode 2014-2016 yang diperoleh dari Bursa Efek Indonesia.

Sumber Data

Sumber data yang digunakan dalam penelitian ini merupakan data sekunder yang berasal dari pojok BEI, yang meliputi:

1. Indonesia Capital Market Directory Bursa Efek Indonesia, yang memuat laporan keuangan tahunan perusahaan;

2. Laporan keuangan perusahaan yang telah dipublikasikan.

\section{Metode Analisis}

Untuk mengola data yang telah dikumpulkan dari hasil penelitian, penulis menggunakan metode analisis deskriptif, artinya data yang diperoleh dilapangan diolah sedemikan rupa sehingga memberikan data yang sistematis, aktual dan akurat mengenai permasalahan yang diteliti. Metode analisis deskriptif yang digunakan untuk menganalisis data yaitu dengan menggunakan rasio yang terdiri dari: Rasio likuiditas, Rasio solvabilitas, Rasio Profitabilitas, Rasio Aktivitas.

HASIL PENELITIAN DAN PEMBAHASAN

Rasio Likuiditas PT Gowa Makassar Tourism Development Tbk.

Tabel 2. Rasio Likuiditas PT Gowa Makassar Tourism Development Tbk

\begin{tabular}{lccc}
\hline \multicolumn{1}{c}{ Ket. } & \multicolumn{3}{c}{ Tahun } \\
& $\mathbf{2 0 1 4}$ & $\mathbf{2 0 1 5}$ & $\mathbf{2 0 1 6}$ \\
\hline Kas & 22.230 .667 .549 & 17.793 .595 .380 & 13.259 .598 .897 \\
Persediaan & 924.374 .621 .827 & 431.447 .130 .782 & 400.233 .971 .687 \\
Aset Lancar & 1.065 .521 .125 .713 & 545.869 .132 .053 & 507.850 .267 .365 \\
Kewajiban Lancar & 510.945 .337 .339 & 512.933 .237 .967 & 435.869 .175 .502 \\
Current Ratio $(C R)$ & $209 \%$ & $106 \%$ & $117 \%$ \\
Quick Ratio $(Q R)$ & $27.5 \%$ & $22.3 \%$ & $24.6 \%$ \\
Cash Ratio & $4.3 \%$ & $3.4 \%$ & $3.0 \%$ \\
\end{tabular}

Sumber: data diolah

Keterangan:

1. Berdasarkan tabel diatas dapat dilihat bahwa besarnya rasio lancar (Current Ratio) PT GMTD Tbk pada tahun 2014 sebesar 209\%, tahun 2015 sebesar $106 \%$ dan tahun
2016 sebesar 117\%. Rasio ini menggambarkan bahwa setiap Rp1 hutang lancar dijamin dengan aktiva lancar sebesar Rp2,09 untuk tahun 2014, Rp1,06 untuk tahun 2015 dan Rp1,17 untuk tahun 2016. 
Hal tersebut menunjukkan bahwa PT GMTD Tbk mampu membayar kewajiban jangka pendeknya dengan aktiva lancar yang dimiliki, walaupun demikian persentase rasio lancar PT GMTD Tbk mengalami fluktuasi persentase, ini disebabkan karena PT GMTD kurang mampu meningkatkan nilai aset lancarnya dari tahun 2014-2016 dan meningkatnya nilai hutang lancar di tahun 2015. Penurunan aset lancar menyebabkan menununnya penambahan persediaan, aktivitas operasi dan biaya pemeliharaan. Di tahun 2014-2015 terjadi peningkatan hutang lancar namun nilai aset lancar mengalami penurunan, sehingga menimbulkan perubahan persentase yang terlampau jauh dari tahun sebelumnya, peningkatan hutang lancar di tahun 2015 terjadi karena pinjaman dana oleh perusahaan ke bank meningkat dan hutang usaha meningkat sehingga nilai hutang lancarnya meningkat. Nilai aset lancar mengalami penurunan dari tahun 2014-2016, hal ini disebabkan oleh berbagai faktor seperti kinerja ekonomi aktiva tidak sesuai harapan dan nilai pasar aktiva mengalami penurunan. Sehingga dapat disimpulkan bahwa kondisi current rasio dalam keadaan sangat sehat karena PT GMTD Tbk mampu membayar semua kewajiban lancarnya dengan aset lancar yang tersedia.

2. Perhitungan Quick Ratio pada PT GMTD Tbk, dari tahun 2014-2016 menunjukkan keadaan berfluktuasi persentase ditiap tahunnya, ini disebabkan karena nilai aset lancar PT GMTD Tbk tiap periode tahunnya mengalami penurunan. Penurunan aset lancar yang tinggi di tahun 20142016 disebabkan karena kas perusahaan dan piutang usaha meningkat, sedangkan pengurangan persediaan di tahun 2014-2015 mungkin dimaksudkan perusahaan agar tidak terjadi penumpukan persediaan. Quick ratio PT GMTD Tbk tahun 2014 menunjukkan nilai $27,5 \%$, artinya bahwa setiap hutang lancar sebesar Rp1 hanya akan dijamin dengan aktiva lancar sebesar Rp0,275. Maka kondisi perbandingan ini dapat dikatakan bahwa PT GMTD Tbk dalam kondisi cukup sehat karena dipandang memuaskan apabila besarnya quick ratio minimal 100\%. Di tahun 2016 nilai quick ratio PT GMTD adalah sebesar $22,3 \%$ mengalami penurunan sebesar $5,2 \%$ dari tahun sebelumnya, artinya setiap utang lancar senilai Rp1 akan dibiayai dengan nilai aktiva lancar sebesar Rp 0,223. Di tahun 2016 nilai quick ratio $\mathrm{PT}$ GMTD Tbk sebesar 24,6\% mengalami kenaikan sebesar 2,3\% dari tahun sebelumnya. Hal ini disebabkan terjadinya penurunan nilai utang lancar di tahun 2016, yakni sebesar 77.064.062.465, artinya setiap utang lancar senilai Rp1 akan dijamin dengan aktiva lancar senilai Rp 0,246. Sehingga dapat disimpulkan bahwa kondisi quick ratio dalam keadaan cukup sehat disebabkan karena meningkatnya nilai hutang lancar.

3. Cash Ratio dari tahun 2014 menunjukkan terjadinya penurunan persentase di tiap periode tahunnya. Hal ini disebabkan karena nilai kas pada PT GMTD Tbk, selalu mengalami penurunan. Di tahun 2014 cash ratio yang dimiliki oleh PT GMTD Tbk adalah sebesar $4,3 \%$, artinya bahwa setiap utang lancar senilai Rp1 hanya akan dijamin oleh aktiva lancar yang berupa kas sebesar Rp0,043 maka kondisi ini dapat dinyatakan bahwa berdasarkan perhitungan cash ratio 
pada tahun 2014 PT GMTD Tbk, berada dalam kondisi cukup sehat karena besarnya aktiva lancar yang berupa kas sebagai jaminan atas utang lancar lebih kecil. Di tahun 2015 nilai cash ratio mengalami penurunan sebesar $0,9 \%$ dari tahun sebelumnya, nilai cash ratio di tahun 2015 adalah sebesar 3,4\%, artinya setiap utang lancar sebesar Rp1 hanya akan dijamin oleh aktiva lancar senilai Rp0,034. Di tahun 2016 nilai cash ratio juga mengalami penununan yakni sebesar $0,45 \%$ dari tahun sebelumnya. Hal ini disebabkan karena nilai aktiva lancar berupa kas di tahun 2016 mengalami penurunan sebesar Rp4.536.996.483. Nilai cash ratio di tahun 2016 adalah sebesar 3,0\%, artinya setiap utang lancar sebesar Rp1 akan dijamin oleh aktiva lancar berupa kas senilai Rp0,030. Sehingga dapat disimpulkan bahwa kondisi cash ratio dalam keadaan sehat karena besarnya aktiva lancar yang berupa kas sebagai jaminan atas utang lancar lebih kecil.

Tabel 3. Rasio Solvabilitas PT Gowa Makassar Tourism Development Tbk.

\begin{tabular}{lccc}
\hline \multicolumn{1}{c}{ Ket. } & \multicolumn{3}{c}{ Tahun } \\
& $\mathbf{2 0 1 4}$ & $\mathbf{2 0 1 5}$ & $\mathbf{2 0 1 6}$ \\
\hline Total Utang & 857.143 .701 .250 & 719.732 .960 .562 & 590.413 .630 .191 \\
Total Aset & 1.524 .241 .388 .731 & 1.273 .990 .253 .786 & 1.229 .172 .450 .340 \\
Total Shareholders & 667.097 .687 .481 & 554.293 .224 & 638.758 .820 .149 \\
equity & & & \\
EBIT & 120.729 .269 .765 & 119.428 .639 .360 & 87.506 .296 .666 \\
Beban Bunga & 5.249 .062 .856 & 2.655 .676 .973 & 3.754 .039 .925 \\
Debt To Assets Ratio & $56 \%$ & $56 \%$ & $50 \%$ \\
Debt To Equity Ratio & $129 \%$ & $130 \%$ & $102 \%$ \\
\hline Sumber: datadiolah & & & \\
\hline
\end{tabular}

Sumber: data diolah

Keterangan:

1. Berdasarkan tabel diatas dapat dilihat bahwa debt to assets ratio PT GMTD Tbk, dari tahun 20152016 menunjukkan terjadinya penurunan persentase. Hal ini terjadi karena total hutang dan total aset relatif mengalami penurunan. Penurunan total aset disebabkan karena nilai kas perusahaan yang selalu menurun di tiap periode tahunnya. Di tahun 2014 nilai debt to assets ratio menunjukkan nilai $56 \%$, artinya bahwa senilai $56 \%$ modal perusahaan dibiayai dengan hutang dan 44\% dibiayai dengan modal sendiri. Di tahun 2015 nilai debt to assets ratio PT GMTD Tbk, adalah sebesar 56\% nilainya sama di tahun sebelumnya, artinya bahwa $56 \%$ modal perusahaan dibiayai dengan hutang dan $44 \%$ dibiayai dengan modal sendiri. Di tahun 2016 nilai debt to assets ratio mengalami penurunan sebesar $6 \%$ dari tahun sebelumnya menjadi 50\%, artinya bahwa modal perusahaan sebesar $50 \%$ dibiayai oleh hutang dan sebesar $50 \%$ dibiayai dengan modal sendiri. Sehingga dapat disimpulkan bahwa 
debt to assets ratio pada PT GMTD menunjukkan kondisi keuangan sangat sehat karena hutang mereka sebagai pembiayaan atas aktiva lebih besar dibanding dengan modal sendiri. Semakin tinggi rasio ini berarti semakin besar jumlah pinjaman yang digunakan untuk membiayai aktiva perusahaan.

2. Debt to equity ratio pada PT GMTD Tbk dari tahun 2014-2016 menunjukkan kenaikan di tahun 2015 namun menurun di tahun 2016, semakin kecil rasio ini menunjukkan semakin kecil pula persentase hutang dalam membiayai modal perusahaan. Penurunan di tahun 2016 disebabkan karena total hutang perusahaan mengalami penununan, sedangkan total modalnya mengalami kenaikan di tahun 2016. penurunan total hutang perusahaan disebabkan karena pembebanan terhadap biaya sewa, kewajiban penghargaan masa kerja, serta pinjaman yang dilakukan pada bank dikurangi oleh perusahaan. Di tahun 2014 nilai total hutang meningkat karena terjadi peningkatan utang sewa yang besar yang dilakukan perusahaan. Hal tersebut dilakukan mungkin untuk promosi-promosi pemasaran produk perusahaan untuk meningkatkan penjualan. Sedangkan peningkatan modal disebabkan karena laba perusahaan yang meningkat, hal ini dikarenakan penjualan yang dilakukan perusahaan cukup tinggi. Tahun 2014 debt to equity ratio menunjukkan nilai $129 \%$, artinya bahwa $1.29 \%$ modal perusahaan dibiayai dengan hutang. Di tahun 2015 nilai DER PT GMTD sebesar $130 \%$ mengalami peningkatan sebesar $1 \%$ dari tahun sebelumnya, artinya bahwa $1.30 \%$ modal perusahaan dibiayai dengan hutang. Dan di tahun 2016 nilai DER 102\%, mengalami penurunan sebesar $28 \%$ dari tahun sebelumnya, artinya bahwa sebagian besar biaya total aktiva dibiayai oleh total utang sebesar $1.02 \%$. Secara umum dapat dikatakan bahwa semakin tinggi rasio ini maka semakin besar resiko kreditor. Sehingga dapat disimpulkan bahwa kondisi DER kurang sehat karena DER lebih besar dari 90\% menunjukkan bahwa sumber pembiayaan aktiva perusahaan lebih banyak berasal dari hutang dibanding dengan modal sendiri.

Tabel 4. Rasio Profitabilitas PT Gowa Makassar Tourism Development Tbk.

\begin{tabular}{lccc}
\multicolumn{1}{c}{ Ket. } & $\mathbf{2 0 1 4}$ & Tahun & $\mathbf{2 0 1 6}$ \\
\hline Penjualan & 301.319 .818 .199 & 303.342 .488 .851 & 276.272 .327 .077 \\
HPP & 128.750 .995 .071 & 135.693 .830 .037 & 141.983 .994 .501 \\
$\quad$ Laba Setelah Pajak & 121.742 .954 .148 & 118.892 .415 .913 & 86.914 .558 .620 \\
Total Aset & 1.524 .241 .388 .731 & 1.273 .990 .253 .786 & 1.229 .172 .450 .340 \\
Total Shareholders & 667.097 .687 .481 & 554.293 .224 & 638.758 .820 .149 \\
Equity & & & \\
NPM & $37,90 \%$ & $39,06 \%$ & $30,33 \%$ \\
ROA & $7,87 \%$ & $9,30 \%$ & $5,75 \%$ \\
ROE & $18,01 \%$ & $21,38 \%$ & $11,78 \%$ \\
\hline
\end{tabular}

Sumber: data diolah

Keterangan:

1. Berdasarkan tabel dapat dilihat 
persentase di tahun 2014-2015 serta penurunan persentase di tahun 2016. Peningkatan di tahun 2015 disebabkan karena penjualan bersih perusahaan mengalami peningkatan karena jumlah pendapatan perusahaan melalui promosi usaha properti mengalami peningkatan, hal tersebut dapat dilihat melalui laporan keuangan perusahaan. Sedangkan penurunan di tahun 2016 dikarenakan nilai laba yang diterima perusahaan di tahun 2016 mengalami penurunan karena besarnya biaya operasional dan pemeliharaan serta kerugian selisi kurs harus ditanggung perusahaa. Nilai net profit margin pada PT GMTD Tbk, di tahun 2014 adalah sebesar $37.90 \%$ yang berarti dari setiap Rp1 penjualan bersih, perusahaan memperoleh laba bersih sebesar Rp 0,3790. Pada tahun 2015 net profit margin perusahaan adalah sebesar 39,06\%, mengalami peningkatan sebesar $1,16 \%$ dari tahun sebelumnya, artinya setiap $\mathrm{Rp} 1$ penjualan bersih perusahaan memperoleh laba bersih sebesar $39,06 \%$ atau $\mathrm{Rp} 0,3906$. Pada tahun 2016 net profit margin perusahaan sebesar 30,33\%, mengalami penurunan sebesar 8,73\% dari tahun sebelumya, artinya setiap $\mathrm{Rp} 1$ penjualan bersih, perusahaan memperoleh laba bersih sebesar 30,33\% atau Rp 0,3033. Sehingga dapat disimpulkan bahwa kondisi Net Profit Margin dalam keadaan sangat sehat disebabkan karena penjualan bersih perusahaan mengalami peningkatan karena jumlah pendapatan perusahaan melalui promosi usaha properti mengalami peningkatan.

2. ROA PT GMTD tahun 2014-2016 menunjukkan terjadi fluktuasi ditiap tahunnya hal ini disebabkan karena besarnya nilai total aktiva relatif menurun dan lebih besar dibanding laba bersih yang diterima perusahaan. Penurunan aktiva ini disebabkan karena kas perusahaan dan piutang perusahaan relatif menurun selama periode 3 (tiga) tahun tersebut. ROA PT GMTD Tbk pada tahun 2014 adalah sebesar $7,87 \%$ yang berarti setiap Rp1 investasi perusahaan memperoleh laba bersih sebesar 7,87\% atau Rp 0,787. Pada tahun 2015 ROA perusahaan adalah sebesar 9,30\%, artinya setiap Rp1 investasi, perusahaan memperoleh laba bersih sebesar $9,30 \%$ atau Rp0,930 dan pada tahun 2016 ROA perusahaan sebesar $5,75 \%$, artinya setiap Rp 1 Investasi, perusahaan memproleh laba bersih sebesar $5,75 \%$ atau $\mathrm{Rp} 0,575$. Sehingga dapat disimpulkan bahwa kondisi ROA dalam keadaan cukup sehat disebabkan karena nilai total aktiva relatif menurun dan lebih besar dibanding laba bersih yang diterima perusahaan, penurunan aktiva ini disebabkan karena kas perusahaan dan piutang perusahaan relatif menurun selama 3 (tiga) tahun tersebut.

3. ROE PT GMTD tahun 2014-2016 menunjukkan terjadinya penurunan dari tahun 2014-2015 dan mengalami peningkatan di tahun 2016. Hal ini disebabkan karena besarnya nilai total equitas relatif meningkat danlebih besar dibanding dengan laba bersih yang diterima perusahaan. Peningkatan equitas ini disebabkan karena pendapatan perusahaan dan saldo laba relatif meningkat. ROE PT GMTD Tbk, pada tahun 2014 adalah sebesar $18,01 \%$, menunjukkan bahwa setiap $\mathrm{Rp} 1$ modal yang disetor pemegang saham, bisnis memberikan tingkat pengembalian sebesar $18.01 \%$ atau Rp0,1801. Di tahun 2015 ROA PT GMTD Tbk, sebesar 21,38\%, menunjukkan bahwa 
setiap $\mathrm{Rp} 1$ modal yang disetor pemegang saham, bisnis memberikat tingkat pengembalian sebesar 21,38\% atau Rp0,2138. Sedangkan pada tahun 2016 ROE perusahaan sebesar 11,78\%, menunjukkan bahwa setiap Rp1 modal yang disetor pemegang saham, bisnis memberikan tingkat pengembalian sebesar 11,78\% atau Rp0,1178. Hal ini menyimpulkan bahwa kondisi ROE cukup sehat disebabkan karena besarnya nilai total equitas relatif meningkat dan lebih besar dibanding dengan laba bersih yang diterima perusahaan. Peningkatan equitas disebabkan karena pendapatan perusahaan dan saldo laba relatif meningkat.

Tabel 5. Rasio Aktivitas PT Gowa Makassar Tourism Development Tbk

\begin{tabular}{lccc}
\hline \multicolumn{1}{c}{ Ket. } & $\mathbf{2 0 1 4}$ & Tahun & $\mathbf{2 0 1 6}$ \\
\hline Penjualan Bersih & 301.319 .818 .199 & 303.342 .488 .851 & 276.272 .327 .077 \\
Rata-Rata Piutang & 759.421 .389 & 1.199 .878 .465 & 263.003 .518 \\
HPP & 128.750 .995 .071 & 135.693 .830 .039 & 141.983 .994 .501 \\
$\begin{array}{l}\text { Rata-Rata } \\
\text { Persediaan }\end{array}$ & 924.374 .621 .827 & 431.447 .130 .782 & 400.233 .971 .687 \\
$\begin{array}{l}\text { Rara-Rata Total } \\
\text { Aktiva }\end{array}$ & 1.524 .241 .388 .731 & 1.273 .996 .253 .786 & 1.229 .172 .450 .340 \\
$\begin{array}{l}\text { Total Aset Turn } \\
\text { Over } \text { (TATO) Inventory }\end{array}$ & 14 kali & & \\
$\begin{array}{l}\text { Turn Over } \text { (ITO) } \\
\text { Receivable Turn Over }\end{array}$ & $3,96 \mathrm{kali}$ & $2,4 \mathrm{kali}$ & $2,2 \mathrm{kali}$ \\
(RTO) & & 31 kali & $35 \mathrm{kali}$ \\
\hline
\end{tabular}

\section{Sumber: Data diolah}

Keterangan Tabel:

1. Berdasarkan tabel diatas Total Assets Turn Over (TATO) PT GMTD Tbk, pada tahun 20142016, dimana menunjukkan peningkatan dari tahun 2014-2015 dan penurunan di tahun 2016. Peningkatan di tahun 2015 disebabkan karena adanya kenaikan penjualan Rp2.022.670.652 dari tahun sebelumnya. Mengalami penurunan di tahun 2016 disebabkan karena adanya penurunan penjualan sebesar Rp27.070.161.774 dari tahun sebelumnya. Di tahun 2014 TATO yang dimiliki oleh PT GMTD Tbk adalah sebesar 2,0 kali yang berarti perusahaan mampu menghasilkan penjualan dari total aktiva yang dimiliki sebesar 2,0 kali dalam setahun. Tahun 2015 sebanyak 2,4 kali yang berarti perusahaan mampu menghasilkan penjualan dari total aktiva yang dimiliki sebesar 2,4 kali dalam setahun. Tahun 2016 sebanyak 2,2 kali yang berarti perusahaan mampu menghasilkan penjualan dari total aktiva yang dimiliki sebesar 2,2 kali dalam setahun.

Sehingga dapat disimpulkan bahwa kondisi TATO sehat disebabkan karena perusahaan mampu menghasilkan penjualan dari total aktiva yang dimiliki.

2. Inventory Turn Over (ITO) PT

GMTD Tbk. Pada tahun 2014-2016 
menunjukkan peningkatan di tiap tahunnya, ini disebabkan karena adanya kenaikan HPP dan diikuti dengan adanya penurunan rata-rata persediaan. Di tahun 2014 ITO yang dimiliki PT GMTD Tbk adalah sebesar 14 kali yang berarti bahwa dana yang tetanam dalam persediaan berputar sebanyak 14 kali dalam setahun. Tahun 2015 ITO perusahaan sebanyak 31 kali yang berarti bahwa dana yang tertanam dalam persediaan berputar sebanyak 31 kali dalam setahun, dan di tahun 2016 ITO perusahaan sebesar 35 kali yang berarti bahwa dana yang tertanam dalam persediaan berputar sebanyak 35 kali dalam setahun. Sehingga dapat disimpulkan bahwa kondisi ITO sangat sehat disebabkan adanya kenaikan HPP dan diikuti dengan adanya penurunan rata-rata persediaan.

3. Recaivable Turn Over (RTO) PT GMTD Tbk pada tahun 2014-2016 menunjukkan penurunan di tahun 2015 dan peningkatan di tahun 2016. Penurunan di tahun 2015 disebabkan karena kenaikan penjualan di tahun 2015 sebesar Rp2.002.670.652 dari tahun sebelumnya dan diikuti kenaikan rata-rata piutang. Di tahun 2014 RTO yang dimiliki PT GMTD Tbk adalah sebesar 3,96 kali, artinya dalam 1 tahun rata-rata dana yang tertanam dalam piutang berputar sebanyak 3,96 kali dalam setahun. Tahun 2015 sebanyak 2,52 kali, artinya dalam 1 tahun rata-rata dana yang tertanam dalam piutang berputar sebanyak 2,52 kali dalam setahun dan di tahun 2016 sebanyak 10.50 kali, artinya dalam 1 tahun rata-rata dana yang tertanam dalam piutang berputar sebanyak 10.50 kali dalam setahun.

Sehingga dapat disimpulkan bahwa kondisi RTO cukup sehat hal ini disebabkan karena besarnya nilai total equitas relatif meningkat dan lebih besar dibanding dengan laba bersih yang diterima perusahaan. Peningkatan equitas ini disebabkan karena pendapatan perusahaan dan saldo laba relatif meningkat.

Tabel 6. Kondisi Kinerja Keuangan PT Gowa Makassar Tourism Development Tbk

\begin{tabular}{|c|c|c|c|c|c|c|}
\hline Ket & 2014 & 2015 & 2016 & Rasio & $\begin{array}{l}\text { Standar } \\
\text { (Kasmir) }\end{array}$ & Kondisi \\
\hline \multicolumn{7}{|l|}{ 1. Likuiditas } \\
\hline a. $\mathbf{C R}$ & $209 \%$ & $106 \%$ & $117 \%$ & $144 \%$ & $>100 \%$ & Sangat Sehat \\
\hline b. QR & $27,5 \%$ & $22,3 \%$ & $24,6 \%$ & $25 \%$ & $<100 \%$ & Tidak Sehat \\
\hline $\begin{array}{l}\text { c. Cash } \\
\text { Ratio }\end{array}$ & $4,3 \%$ & $3,4 \%$ & $3,0 \%$ & $4 \%$ & $<50 \%$ & sehat \\
\hline $\begin{array}{r}\text { 2. Solvabilitas } \\
\text { a. DAR }\end{array}$ & $56 \%$ & $56 \%$ & $50 \%$ & $54 \%$ & $>35 \%$ & Sangat Sehat \\
\hline b. DER & $129 \%$ & $130 \%$ & $102 \%$ & $120 \%$ & $<90 \%$ & Tidak Sehat \\
\hline \multicolumn{7}{|l|}{ 3. Profitabilitas } \\
\hline a. NPM & $37,90 \%$ & $39,06 \%$ & $30,33 \%$ & $36 \%$ & $>20 \%$ & Sangat Sehat \\
\hline b. ROA & $7,87 \%$ & $9,30 \%$ & $5,75 \%$ & $8 \%$ & $<30 \%$ & Cukup Sehat \\
\hline c. ROE & $18,01 \%$ & $21,38 \%$ & $11,78 \%$ & $17 \%$ & $<40 \%$ & Cukup Sehat \\
\hline \multicolumn{7}{|l|}{ 4. Aktivitas } \\
\hline a. ТАTO & $2 x$ & $2,4 x$ & $2,2 \mathrm{x}$ & $2,2 \mathrm{x}$ & $>2 x$ & Sehat \\
\hline b. ITO & $14 x$ & $31 x$ & $35 \mathrm{x}$ & $26 \mathrm{x}$ & $>20 x$ & Sangat Sehat \\
\hline c. RTO & $3,96 x$ & $2,52 x$ & $10,50 \mathrm{x}$ & $5 \mathrm{x}$ & $>15 x$ & Cukup Sehat \\
\hline
\end{tabular}


Dari tabel diatas, maka interpretasi kondisi kinerja keuangan PT Gowa Makassar Tourism Development Tbk sebagai berikut:

1. Kondisi kinerja keuangan dilihat dari rasio likuiditas

a. Current Ratio

Secara keseluruhan rata-rata current ratio PT. Gowa Makassar Tourism Development Tbk pada periode 2014-2016 sebesar 144\%. Dengan demikian current ratio PT Gowa Makassar Tourism Development Tbk dikatakan sangat sehat karena di atas rata-rata angka standar.

b. Quick Ratio

Secara keseluruhan rata-rata quick ratio $\mathrm{PT}$ Gowa Makassar Tourism Development Tbk pada periode 2014-2016 sebesar 25\%. Dengan demikian quick ratio PT Gowa Makassar Tourism Development Tbk dikatakan tidak sehat karena di bawah rata-rata angka standar.

\section{c. Cash Ratio}

Secara keseluruhan rata-rata cash ratio PT Gowa Makassar Tourism Development Tbk pada periode 2014-2016 sebesar 4\%. Dengan demikian cash ratio $\mathrm{PT}$ Gowa Makassar Tourism Development Tbk dikatakan sehat, walaupun jauh dibawah angka standar $<50 \%$, bisa dilihat dari aktiva lancar yang berupa kas sebagai jaminan atas utang lancar jauh lebih kecil.

2. Kondisi kinerja keuangan dilihat dari rasio solvabilitas

a. Debt to assets ratio

Secara keseluruhan rata-rata debt to assets ratio PT Gowa Makassar Tourism Development Tbk pada periode 2014-2016 sebesar 54\%. Dengan demikian debt to assets ratio PT Gowa Makassar Tourism Development Tbk dikatakan sangat sehat karena di atas rata-rata angka standar.

b. Debt to equity ratio

Secara keseluruhan rata-rata debt to equity ratio PT Gowa Makassar Tourism Development Tbk pada periode 2014-2016 sebesar $120 \%$. Dengan demikian debt to equity ratio PT Gowa Makassar Tourism Development Tbk dikatakan tidak sehat karena di atas rata-rata angka standar.

3. Kondisi kinerja keuangan dilihat dari rasio profitabilitas

a. Net profit margin

Secara keseluruhan rata-rata net profit margin PT Gowa Makassar Tourism Development Tbk pada periode 2014-2016 sebesar $36 \%$. Dengan demikian net profit margin PT Gowa Makassar Tourism Development Tbk dikatakan sangat sehat karena di atas rata-rata angka standar.

b. Return on assets

Secara keseluruhan rata-rata Return on assets PT Gowa Makassar Tourism Development Tbk pada periode 2014-2016 sebesar 8\%. Dengan demikian return on assets PT Gowa Makassar Tourism Development Tbk dikatakan cukup sehat karena di bawah rata-rata angka standar.

c. Return on Equity

Secara keseluruhan rata-rata Return on equity PT Gowa Makassar Tourism Development Tbk pada periode 2014-2016 sebesar 17\%. Dengan demikian return on equity PT Gowa Makassar Tourism Development Tbk dikatakan cukup sehat karena di bawah rata-rata angka standar.

4. Kondisi kinerja keuangan dilihat dari rasio aktivitas 
a. Total assets turn over

Secara keseluruhan rata-rata Total assets turn over PT Gowa Makassar Tourism Development Tbk pada periode 2014-2016 sebesar 2,2 kali. Dengan demikian Total assets turn over PT Gowa Makassar Tourism Development Tbk dikatakan sehat karena di atas rata-rata angka standar.

b. Inventory turn over

Secara keseluruhan rata-rata Inventory turn over PT Gowa Makassar Tourism Development Tbk pada periode 2014-2016 sebesar 26 kali. Dengan demikian Inventory turn over PT Gowa Makassar Tourism Development Tbk dikatakan sangat sehat karena di atas rata-rata angka standar.

c. Receivable turn over

Secara keseluruhan rata-rata receivable turn over PT Gowa Makassar Tourism Development Tbk pada periode 2014-2016 sebesar 5 kali. Dengan demikian Receivable turn over PT Gowa Makassar Tourism Development Tbk dikatakan cukup sehat walaupun jauh dibawah rata- rata angka standar, bisa dilihat dari nilai total equitas lebih besar dibanding dengan laba bersih yang diterima perusahaan.

\section{KESIMPULAN}

Berdasarkan hasil penelitian dan pembahasan yang dilakukan oleh peneliti pada PT Gowa Makassar Tourism Development Tbk, maka peneliti menyimpulkan:

1. Kinerja keuangan PT GMTD Tbk sudah berjalan dengan baik walaupun tiap rasionya menunjukkan fluktuasi, berdasarkan hasil perhitungan yang dilakukan dengan menggunakan rasio likuiditas, solvabilitas, profitabilitas dan aktivitas, menunjukkan pengelolaan keuangan perusahaan cukup berjalan dengan baik.

2. Kinerja PT GMTD Tbk berdasarkan rasio likuiditas pada tahun 2014 sampai tahun 2016 berada dalam keadaan sehat meskipun berfluktuasi, dimana Current Ratio (CR) perusahaan dalam kodisi sangat sehat dimana CR sebesar 144\%. Itu artinya PT GMTD Tbk mampu membayar semua kewajiban lancarnya dengan aset lancar yang tersedia. Quick ratio secara keseluruhan dalam kondisi cukup sehat disebabkan karena meningkatnya nilai hutang lancar.

3. Rasio solvabilitas PT GMTD Tbk pada tahun 2014-2016 dalam kondisi cukup sehat dimana Debt To Assets Ratio (DAR) perusahaan rata-rata sebesar 54\%. Persentase ini menunjukkan bahwa kondisi keuangan sangat sehat karena hutang mereka sebagai pembiayaan atas aktiva lebih besar dibanding dengan modal sendiri. Sedangkan Debt to equity ratio (DER) perusahaan memiliki kondisi kurang sehat karena DER lebih besar dari 90\% menunjukkan bahwa sumber pembiayaan aktiva perusahaan lebih banyak berasal dari hutang dibanding dengan modal sendiri.

4. Rasio profitabilitas PT GMTD Tbk pada tahun 2014-2016 adalah kurang sehat, dimana hasil perhitungan rasio profitabilitas lebih besar dari suku bunga deposito berjangka satu tahun.

5. Rasio aktivitas PT GMTD Tbk pada tahun 2014-2016 dalam keadaan sehat dimana Total Assets Turn Over (TATO) lebih dari 1 (satu) yang artinya perusahaan produktif dalam menghasilkan penjualan. Sedangkan kondisi ITO sangat 
sehat disebabkan adanya kenaikan HPP dan diikuti dengan adanya penurunan rata-rata persediaan. RTO cukup sehat hal ini disebabkan karena besarnya nilai total equitas relatif meningkat dan lebih besar dibanding dengan laba bersih yang diterima perusahaan.

\section{SARAN}

Adapun saran-saran yang dapat penulis berikan sehubungan dengan hasil penelitian ini adalah sebagai berikut:

1. PT GMTD Tbk, hendaknya dapat meningkatkan dan mempertahankan kemampuan perusahaan dalam kewajiban membayar hutang jangka pendeknya dengan segala aktiva lancar yang dimilikinya dengan cara mengurangi hutang lancar setiap tahunnya sehingga tidak terjadi fluktuasi dan dapat optimal dalam memenuhi kewajiban jangka pendeknya.

2. PT GMTD Tbk,hendaknya lebih meningkatkan efektivitas penggunaan aktiva dengan cara meningkatkan penjualan sehingga perusahaan lebih produktif.

3. PT GMTD Tbk hendaknya dapat mempertahankan dan meningkatkan lagi kemampuan perusahaan dalam menghasilkan laba agar semakin baik dalam mengelola perusahaan.

4. Kepada peneliti selanjutnya yang ingin melakukan metode Rasio Keuangan pada jenis perusahaan berbeda, dianjurkan untuk memilih perusahaan yang memiliki laporan keuangan yang lengkap agar analisis Rasio Keuangan dapat lebih maksimal.
DAFTAR PUSTAKA

Ribo, Agustinus. 2013. Analisis Laporan Keuangan untuk Menilai Kinerja Keuangan Perusahaan Telekomunikasi yang Terdaftar di BEI. Skripsi. Makassar. Universitas Hasanuddin.

Jumigan. 2006. Analisis Laporan Keuangan. Jakarta: PT. Bumi Aksara.

Astuti, Dewi. 2004. Manajemen Keuangan Perusahaan. Edisi Pertama. Penerbit. Ghalia Indonesia.

Jones, Charles. 1998. Event Studies in Economic andFinance. Joumal of Economic Literatre. VolumeXXXV.

Mulyadi. 2007. Balance Scorecard: Alat Manajemen Kontenporer untuk Pelipa Ganda Kinerja Keuangan Perusahaan. Edisi Kedua. Yogyakarta: Aditya Media.

Muslich, Muhammad. 2000. Manajemen Keuangan Modem: Analisis Perencanaan dan Kebijakan. Jakarta: Bumi Aksara.

Irawati, Susan. 2006. Manajemen Keuangan. Bandung: Pustaka

Harahap. 2004. Akuntansi Aktiva Tetap. Edisi Ketiga. Jakarta: PT. Raja Grafindo Persada.

Ardiyos. 2008. Kamus Besar Akuntansi. Jakarta : Citra HartaPrima.

Harahap. 2011. Analisis Kritis Atas Laporan Keuanga. Jakarta: PT. Raja Grafindo Persada.

Fahmi, Irham. 2014. Analisis Kinerja Keuangan. Bandung: Alfabeta. 